Progress Report for the lonth of Apri1, 1947

Contract No, W-38-094-eng-27

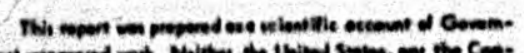

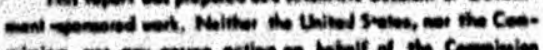

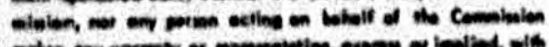

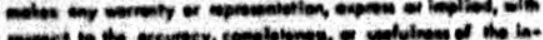

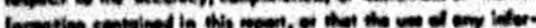

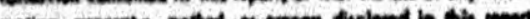

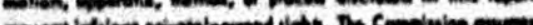

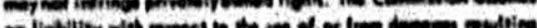

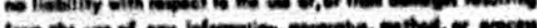

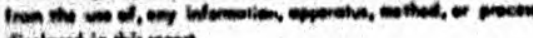
dinclowed in thin nopent.

The firet page of this roport is pase 19/.

Apr11 30, 1947
E. J. Center
H. R. Holson
H. A. Pray
A. C. Rdchardson

Photostat Price $\mathbf{s}$

Mierofilm Price

4.80

Avolilablo from the

Office of Technical Sorvices

Dopertment of Commoree

Woshington 25, D. C.

tho strot paco of the report do paco 1910

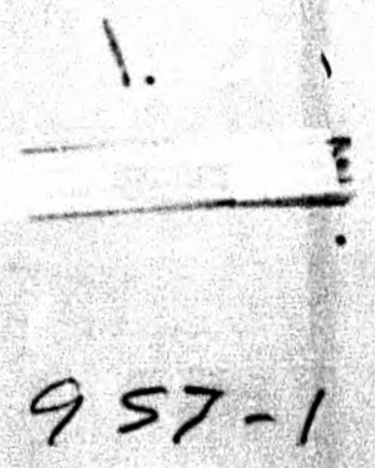


Progress Report for the lonth of Apri1, 1947 Contract No. 1-38-094-eng-27

\section{TABLS OF COITEAMS}

Pege

suchary ......................... 175

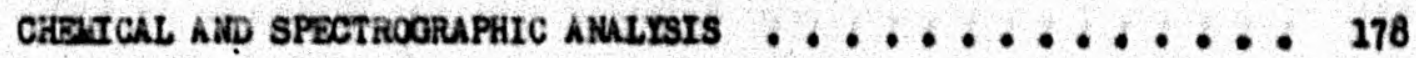

Spectrographic ................. 178

Wet Chemistry ................. 178

CHEMGal work . . . . . . . . . . . . . . . 179

SUPERPHOSPHATE LEACHINO ............ 179

URANIUE RECOVERY .................. 182

Precipitation of Uranium with Organic Reagents .... 182

Uranium Extraction with Bther ........... 184

SUPRRPHOSFHATE RECOVERY ............... 285

AIALYSTS OF SHLPLES FROV AMACONDA PHOSPHORIC ACID PLANT . 185 BETh-COUMIINO WBTHODS or AMLYSIS ............. 186 ORE-DRESSINO AND PYRONEThLLUROICAL STUDTES . . . . . . 187

OHE-DRESSINd STUDIES . . . . .......... 187

PYROMEThLLURGICAL WORK ................ 188

Use of Sulphur Chloride ............. 190

afl-Shale Jistillation ............ 190

Thenalc Heductions ............... 191

Pyrometallurgical Tests in a Vacuum furnace ...... 192 
Proctece Report for the Honth of Apgil, 1947

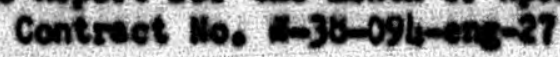

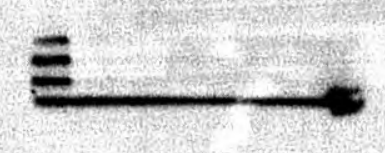

\section{ITST of ZABuss}

Pere

Table 50. Latching Superphoophate Hith a "Saturated" superphosphates solution ........... 181

Tab10 51. Reoults of Uraniul Preclpitation by laines fros 50 as. of U/200 ce. of Solutions, pH slightly Belon $2 \ldots \ldots . . \ldots . . . . . .183$

Table 52. Analyses of Anaconda Prodicts ......... 185

Table 53. Reaules of Clagalfloation and Heery thquid Separations on Roagted sanples of Itabo Phosphato Rock . . . . . . . . . . 289 
Proenes Roport for the lonth of Apits, 1947 Contreet Ho. $=30-094-e n k-27$

\section{LIST OF FOURES}

Pere

Figure 3. Eectrle Induetion Furnace for Vacuu

Teating ................. 293

Fygure 4. PSB Puaping Systen and Induction Purnace

Front view ................. 294

Figure 5. PSg Pumpling System and Induetion Purnace

Rear vien ............... 195

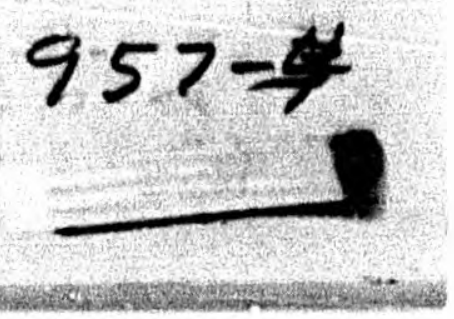




\section{Progress Meport for the vonth of hpr13, 1947} Contract No. "i-36-094-eng-27

\section{SUMuRY}

In ore dressing, / the last theee sauples of Idaho phosphate rock wore treated so as to obtain rrom nsch of them the separate products, one of wich was enriched in quartz and the other enriched in phosphate. $>$ Based on th-counts, the urentiventents of the quarts fractions were consistentiy low, the assays verying from one-rifen to one-half as high as the corresponding head assay. "f the -umberente contents of the phosphate frections were slightly but not significantly higher than the head sasplesof These date substantiato previous evidence that the uranium is disseminatad throughout the phosphate and cannot be concentrated to any extent by means of a practicable physical separation.

\footnotetext{
$2 /$ In the pyrometallurgical work a number of test were tried, the re-
} sults of which are brieny sumarized.

The removal of volatile unentle compounds from the heated shalo-ore charge (Sample $2090-4)$ is apparently not alded by sweeping with large volumes of alphus chlorlde gas.

Results of distillation tests on the o1l-shale sample indicate that it is possible to recover 5 gallons of ofl per/ton of shale as a distiliate in a preheating period.)

The thernic-reduction tests, using $\mathrm{Mg}_{\mathrm{g}} \mathrm{Ml}, \mathrm{Fe}$, or $\mathrm{Zn}$ gave no Indication

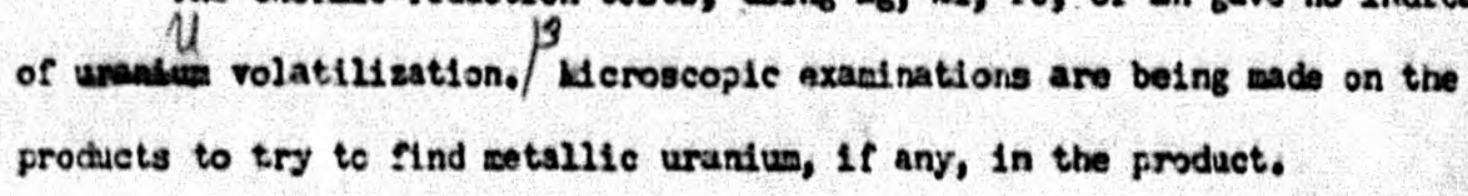

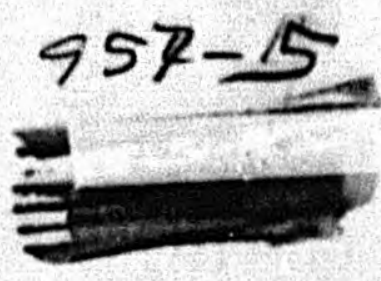


The vacuus furnace testing was carried out on a phosphoras furnace slag and on varlous charses of Ores 4,8 , and 11 . There are few data to give basis for conclusive Interpretations. Bstimationt of uranius concentrstions In the residues by 3-count assays gave indecisive indications that there was no appreciable resoval of uranitue fron any of the experimental sasples ( 4,6 , and 41 ) by heating, saelting, or ehloridizing under vaeuuas of less than 1 micron.

5/Excellent recoveries of ursnium rrom synthetic phosphoric acid

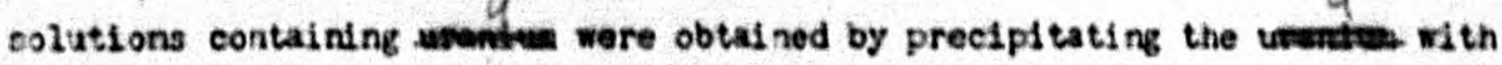
organic amines. The ashed products contained as mueh as 60 opepreant of urentere consistently over $70 \%$ peeneente / It was more difficult to get satisfactory precioitates from synthetic calciun phoepate solutions and still more difficult from leach solatlons, but on the whole t.re results were highiy encouraging.

$4 /$ is nety-four to $98 \%$ per-oeat of the wrantion in superphosphate leach solutions was recovored by ether extraction in the presence of $30 \%$ pentorent $\mathrm{Te}\left(\mathrm{NO}_{3}\right)_{3}$ serrie-nitress. The recovery was lowered by rectucing the amount of seveive and ond

ittempts to prepare "saturated" superphosphate solutions and to use them for leaching the uranium frow superphosphate were not very encouraging because of low net extraction. Ton nuch uranium was lost to the residue in retalned leach solutinn.

At:erapts to reconstruct superphospiate froia mixtures of leach residues and colutions were also highly ensouraging. Such mixtures were evaporated to 
-177-

Progress Report for - Honth of Apri1, 1947

Contract Wo. $1-38-094$-ens -27

about the ease velght os the original superphosphate and were then found to have about the sase soluble satter. Thlo Indleates that Iltile, if any, of the soluble phosphate was lost.

Sumary reports on both chealcal and physical sethode of analysis for uranie in trace easounts are in proparation. 
Progress Report for the Wonth of Apr11, 1947

Contrect No. 1t-38-09/4-eng-27

\section{CKRMACAL AND SPBCTROORA PHIC ANALYSIS}

(B. J. Center, Assistant Supervisor)

\section{Spectrographice}

The possibility of using electron multiplier phototubes in the analysis of ores and rocks for small amounts of uranlun 10 being investlgated. Wr. W. Wo Henry will talk to Dr. O. H. DAleke at Johns Hopkins Und veralty on April 25, 1947, about the application of these tubes to spectrographic trace analysis in general.

\section{Wet Chemistry}

Work is proceeding on a mothod for the drect extrection of uranium from solutions containing large amounts of phosphate, This problen is being conaldered from both an analytical and large-scale recovery point of viow.

$\mathrm{Fo}\left(\mathrm{NO}_{3}\right)_{3}$ has proven to be the most affective salting-out agent of those Investigated to date. By adding 30 per cont of $\mathrm{Po}\left(\mathrm{NO}_{3}\right)_{3}$ to an aquaous superphosphate lesch(1), and extracting with othyl ether for one hour at room tamperature in a continuous extractor, 100 per cont uraniun recoveries have been obtained. Adding 15 per cent of $\mathrm{Fe}\left(\mathrm{NO}_{3}\right)_{3}$ and extracting the above solution in the same manner resulted in a 25 por cent urani um recovery, but if the extraction was sarried out at $0^{\circ} \mathrm{C}$, , the recovery of uraniun rose to 45 per cent ${ }^{(2)}$.

(1) No. 12803. See section on chearical nork. The phosphate lesch solution contained $4.4 \mathrm{mg} . \mathrm{U}$ and $28.7 \mathrm{~g} . \mathrm{P}_{2} \mathrm{O} 5$ per $200 \mathrm{ml.t}$

$$
\frac{\mathrm{P}_{2} \mathrm{O}_{5}}{\mathrm{~V}} \cdot 4250
$$

(2) Three per cent nitric acid was added to the aquevus phase in all the $\mathrm{Fe}\left(\mathrm{NO}_{3}\right)_{3}$ extractions.

$$
957-8
$$


Progress Report for the Wonth of April, 1947

Contraet No. 1 -38-094h-eng-27

Plane are boing ade to expand the extraction phase of the program.

A topleal report on Battelle analytical methods for the deternalnation of small amounts of uranium in phosphates, shales and thei $r$ products is being prepared.

\section{CHEMCAL WORK}

(H. A. Pray, Supervisor)

Attention was paid almost entirely to preparation of and leaching with "saturated" superphosphate solutions and to recovery of uranium from the leach solutions. Some additional work was done on leaching phosphate rock with carbonates and shale with acid, but this is not reported because chendcal analyses are not yet avaliable.

\section{SUPERPHOSPHATE LEACHINO}

As explained in last month's roport, it was thought that a solution saturated with respect to superphosphate might be an efficient leach solution which would not dissolve wuch of the superphosphates, but would remove the uramium. Preparation of such a solution was attempted but was found to be difficult, if not impossible.

When an excess of superphosphate was stirred with water there was a steady increase in density until, at a donsity of 1.5 , the solution becase too syrupy to mork. Furthermore, the solution became more acid. This indicated a shd fting ratio between $\mathrm{CaO}$ and $\mathrm{P}_{2} \mathrm{O}_{5}$ in the direction of increased free $\mathrm{P}_{2} \mathrm{O}_{5}$ in solution. Apparently, in dissolving, the sonocalcium phosphate was partiy composed to dicalcium phosphate and phosphoric acid.

$$
957-9
$$


Progress Report for the Wonth of Apr11, 2947 Contract No, $1-38-094-e n g-27$

Atterpto were made to leach batches of auperphosphate with solutions prepared in the manner described, but which had not yot reachod the syrupy stage. For example, a superphosphato solution containing 63 ng. uraniue per I1ter and whlch had a denslty of 1.29 was used to leach one batch of superphosphate. The reaults aro given in Table 50.

The result was that uranium concentration of the solution was Increased from $63 \mathrm{age} / 1$. to $80 \mathrm{mge} / 1$. but the not amount of urani un extracted was only 2.5 mge, or 20 per cent of that present in the superphosphate. About 60 milliliters of the leach solution was left on the leached realdue and this contained $4.8 \mathrm{mg}$. of uranilum. If none of the leach solution had been left on the resicue the extraction would have been about $7 \mathrm{gge,}$ or over 50 per cent of that contained in the euperphosphate. Although the asount of solution left on the residue may possibly be reduced by bettor tochnique, it appesro that a high net extrection of uraniun is unlikely by this method.

The solution with a specifle gravity of 1.29 dissolved 20 per cent of the superphosphate, or nearly half as much as is usually dissolved by water. Its density increased to 1.33. Solution with denaities higher than this were so syrupy that they were difficult to filter.

The only materials at prosent fvadlable for the leaching tests are superphosphates prepared in the laboratory, and a Sacco brand 20 per cent superpnosphates purchased on the open market. The forner necessarily varies somewnat in compositior. from batch to batch. The origin of the second is not known, or is the conditioning treatment to which 1 t has been subjected known. Both cuntain about the same amount of uraniun, $0.006-0.007$ per cent by beta count. The laach solutions from the laboratory-propared superphosphates were more acid than those from the Sacco prockuct. The pHs of the solutions 
Progrees Roport for the Honth of Apr-11, 1947 Contreet $110.16-38-094-e n B-27$

TABLE 50. LEACHING SUPERPHOSPHATB WITH A "SATURATE" SUPERPHOSPHATE SOWTICN

\begin{tabular}{|c|c|c|c|c|c|c|c|c|c|c|}
\hline & & & & & & & & Unend & & \\
\hline & $\frac{\text { Volume }}{\text { Bofore }}$ & $\frac{\text { cen }}{\text { Irter }}$ & $\frac{\text { Vestint }}{\text { Before }}$ & $\frac{\text { Re }}{\text { After }}$ & $\begin{array}{l}\text { Lose, } \\
\$\end{array}$ & 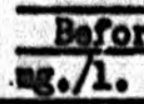 & $\frac{e_{B}}{m_{0}}$ & $\frac{A 10}{28 / 10}$ & 8 & $\begin{array}{l}\text { Ectrected, } \\
8\end{array}$ \\
\hline Solutson & 400 & 340 & 516 & 452 & 12 & 63 & 25 & 80 & 27.5 & 20 \\
\hline $\begin{array}{l}\text { Superphos- } \\
\text { phate }\end{array}$ & - & - & 190 & 152 & 20 & - & - & - & - & - \\
\hline
\end{tabular}


Progrese Report for the Honth of Aps11, 1947 Contrect Ho. W-38-094-ong-27

were 0.5 to 1.0 and 2.5 to 3.0 , respectively. About trice as much of the urande in the laboretory product was water-solublo es of that in tho othor. Bocelpt of tho suporphosphato fros tho Forlda rock would holp this oltuation.

URANTU RECOVERY

As Indioatod in lest month's roport, two mothods for rocovering uranium frod loach solutions are being inveotlgated. Thoy are (1) proelpitation with organde reagents, and (2) extrection with an organic 001 vont.

\section{Procipitation of Urentive with Organic Rearente}

Uranium was proelpitatod noarly quantitativily with eninos from phosphoric acid solutions containing 500 and 50 ag, of V par L1tor. Table 51 gives the results by beta-count and chasical analysis. Tha bote-count analyses on the $500 \mathrm{mg}$ /1. solutions are lese rellable than tho chemical analyes because they were based on a olnglo reading taken a short tine aftor the proelpitation. The others were based on eeveral readings mads at intervalo of several daye and are belleved to bo eore rollablo.

The 1gmited preelpitates were high in unaniun, They contalned 50 to 80 per cent of the metal. Tetraethylenepentamine was the best precipitant of those tried. The Eajor part of the tests on the nore diluto uranilu solutions were made with 1 t.

Tests made on synthetic leach solutions which had been propared from monocalcium phosphate phosphoric seld and urenyl nitrato, water leach solutions from laboratory prepared superphosphate, and water leach solutions from Sacco brand superphosphate purchased on the open Earket have not been so definits.

$$
957-12
$$


Progrees Report for the Konth of Aprl1, 1947

Contrect $110.11-30-094-a n g-27$

TAERE 51. RESULTS OP URANTUM PRECIPITATION BI ALIMES PROK $50 \mathrm{ng}$.

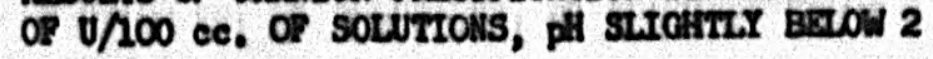

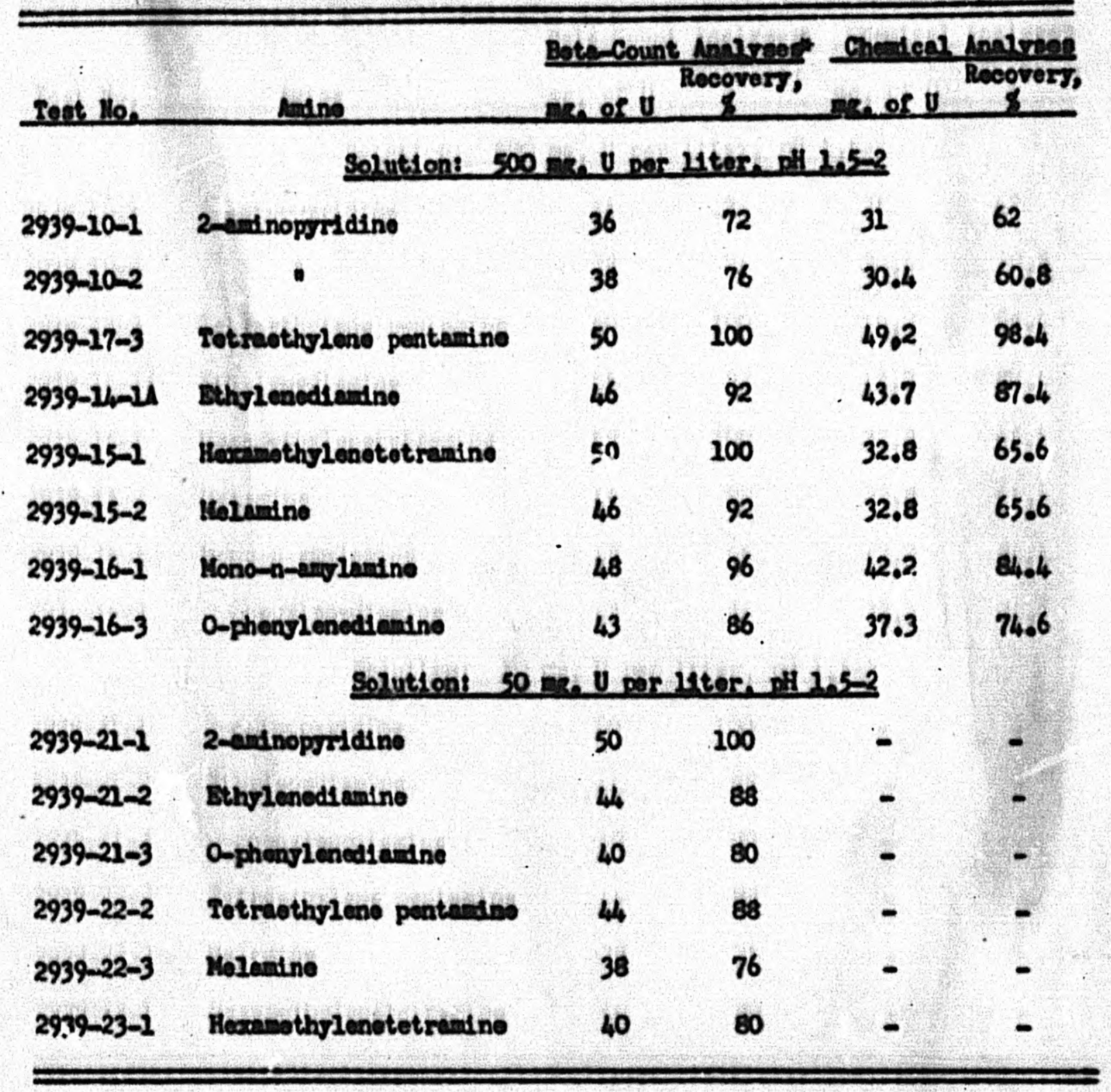

- Becount analyees on the $500 \mathrm{gs} / \mathrm{A}$. 8olutions based on a oingle count; the others on three, or more. 
Synthetic calcium phosphate solutions and leach solutions from superphosphate did not react simdlarly to precipitation, at least in so far as could bo doternined from beta-count analyses. Cheaical analyses are not yot complote. The beta-count indicated higher uranilu precipitation from tho synthetic calcium phosphate solutions. In general, however, the results are encouraging. On the basis of preliminary experiments it was thought that carbon dloxd de In the superphosphate leach solution might prevent precipitation of the uranium. Further tests with $\mathrm{CO}_{2}$ saturated and unsaturated solutions Indicate that carbon dioxd de may be of minor importance.

Another possible interfering ion is fluoride. The effect of this on uraniun precipitation will be investigated.

So far only amines have been studied as precipitants. Other classes of reagents, notably nitrogen-sulphur compounds and phenolic acids, will be tried.

\section{Uranium Extraction a1th Ether}

The extraction of uraniun from superphosphate leach solutions is described in the analytical section of this report. In the presence of 30 per cent of ferric ndtrate in the leach solution, 94 to 98 per cent of the uraniun was extracted in one hour. When the amount of ferric nitrate saltingout agent was reduced to 15 per cent, the extraction dropped to 45 per cent. Sthyl atner is the only solvent tried so far.

Solutions containfing as much as 30 per cent of ferric nitrate could not be uzed for leaching superphosphates. When such a solution was mixed with the latter, the mixture set to a gel. What effect ferric nitrate and other slmilar salts would have on the avallability of the phosphate remains to be deternined.

$$
957-14
$$


Progress Report for the Lonth of Apr-11, 1947

Contract Iio. in-38-094i-ens-27

\section{SUPBRPHOSPHATE RECOVERY}

Recently consideration has been given to recovery, or reconstruction, of superphosphate from leach residues and leach solutions which bave been stripped of uranium. Slurries were prepared from proper proportions of these products and evaporated to the same weight as the original superphosphate.

The procucts were examined for water-soluble matorial, physical properties as compared to superphosphate, and avallable phosphate. No loss In water solubility was observed on the reconetructed) superphospnate. Its physical properties, 1.e., granulation, crushability, dryness, color, and similar properties were hardly distinguishable from those of the original superphosphate. Chemical analysis has not yet been completed but the observation that no loss in water solubility occurred strongly indicates that none of the soluble phosphates were lost by leaching and evaporation.

\section{ANALYSIS OF SAMPLES FROM ANACONDA PHOSPHORIC ACID PLAMT}

Samples of raw rock, filter cake, and vanadium red cake were recelved from the U. S. Oeological Survey. Analyses, given in Table 52, show that the uranium must be extracted with the crude phosphoric acld as neither the red cake nor the filter cake contain 1t. A sample of the ac1d was not Included with the others.

TABLE 52. ARALYSBS OF ANACONDA PROEUCTS

\begin{tabular}{ll}
\hline \hline Product & $0, \%$ \\
\hline Raw rock & 0.010 \\
Red cake & 0.002 \\
Filter cake & $0.002 \quad 957$ )
\end{tabular}


Progress Report for the Konth of Apr11, 1947

Contract No. $W-38-094$-eng-27

\section{BSTA-COUMTINA LETHODS OF ALULYYSIS}

(H. R. Nolson, Supervisor)

Spot testo to deternine whother the beta-count analyees of the ores and diluted synthetic ores are in error because of high-emanating power (continual loss of radon) were made on Ore 1 (Tennessee shale), Ore 8 (Idaho phosphate rock), Ore 11 (norlds pebble phosphate rock), and NBS-2230-1-kS-UL (Gianadian uraninite). These tests were made by sealing the ores in polystyrene briquettes to trap possible emanation, and measuring the change of activity With time. An iricrease of activity proceeding according to the half-1ife of radon would indicate an increase in the amount of radon in the sample caused by entrapment in the plastic. No sensible increase was observed in any of the samples, it is concluded that there is no error in beta-count analyses of these orss oring to radon emanation.

The toplical report on beta-counting methods is being revised and eated. 
Progreses Report for the Honth of Apsil, 1947 Contract No, E-38-094-eng-27

\section{ORE-DRESSINO AMD PYROYGTALUROICAL STUDIES}

(A. C. Rdchardeon, Supervisor)

\section{ORE-DRESSI IB STUDTES}

The progress reports for February, 1947, and Uareh, 1947, otated the conclualon that no elgnificant concentration of urent um was obtained by the concentration of the major phases of samples $1090-1,-4,-7$, and -9 , the Tennessee shales, Sample 190-11, a Florids pebble phoophates and seaple 1090-8, in Idaho phosphate rock.

This month ofintlar data have been obtained on the three rematning samples, $2090-3,-5$, and -6 , all Idaho phosphates.

The procedure used in ceparating the phasee of thase three samples was that doveloped as a result of the experience with Sample 1090-8. In each case the organic netter was removed by roasting (at 14,00\%. for Sauples 1090-3 and $1090-6$, at $1900^{\circ} \mathrm{F}$. For Semple 1090-5), and tho roasted product was around and eoparated Into three fractions by water elutriation. These wore as follnwes

\begin{tabular}{|c|c|c|}
\hline Proguct & Settiling Bate & $\begin{array}{l}\text { Hoalnal sise, Merons } \\
\text { Based on Cuarts . Spherees) }\end{array}$ \\
\hline Coarse eand & over $5 \mathrm{cmo} / \mathrm{min}$. & Over 30 \\
\hline Intornediato & Botween 1.4 and $5 \mathrm{ca} / \mathrm{dm}$. & 25 to 30 \\
\hline Plno & Under $1.4 \mathrm{cmo} / \mathrm{min}$. & Undor 15 \\
\hline
\end{tabular}
coarse was not used because of insurflcient Lberation, the aline prochet was discardad because its perelotont nocculation gave a poor separation. Two specifle grapities were used to closely brackot quarts, wid to give a heevier

$$
\text { 95?-1) }
$$


Progreas Report for the lonth of April, 1947 Contrect No, N-38-094-ens-27

and 14ghter product as woll. Tho products wore all analyed for urantum content by the beta-count mothod, tho produet high in quarts was also analyeed for sllics content.

The results are ahom in Table 53. The conclusions for all three samples are sinflar and can be cliscuesed as ono. No change 1s shown in tho uranium content $\mathrm{m}$ th change in partiele a1se. The 2.60 to 2.68 specific gravity portions, which are the fractions enriched in quarts, contain from 76 to 87 per cent of $\mathrm{S1O}_{2}$ and only 0.001 to 0.004 per cent of uranilum. This 18 only $1 / 5$ to $1 / 2$ of the uranium assay of the head samples and 1ndicates that there is no concentration of the uraniun with the quarts. The fractions over 2.68 specific grapity, which consist of relatively clean phoophate, are slightly but not significantly higher in uranium contents than the head samples. It is concluded that no practicable concentration ef uranium by phyaical methods is possible with these samples.

When the chemical analyses are completed on these samples it is planned to prepare a table that will show the approxdmate mineral composition and the uranium distribution in the major phases for all of the samples examined. Other than this, no surther ore-dressing studies are contemplated on these particular eamples.

\section{PYROMETALUROTCAL WORK}

This report covers the work during the period April 1 to April 30, 1947 , on the elimination of uranius from low-grade ore samples by pyromotallurgical means. The rork is divided into the following phasest use of sulphur chloride as a volatilizing agent, thermic reductions by motalo, oilsivale distillations, and vacuum testing.

$$
975 \cdot 18
$$


Progrees lleport for the Mlonth of Aprly, 1947 Contrect Ho. 1-38-0\%4-eng-27

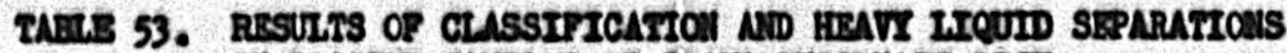
OA ROASTE SMMPLES OF IDAHD PEDSPHATE BDOS

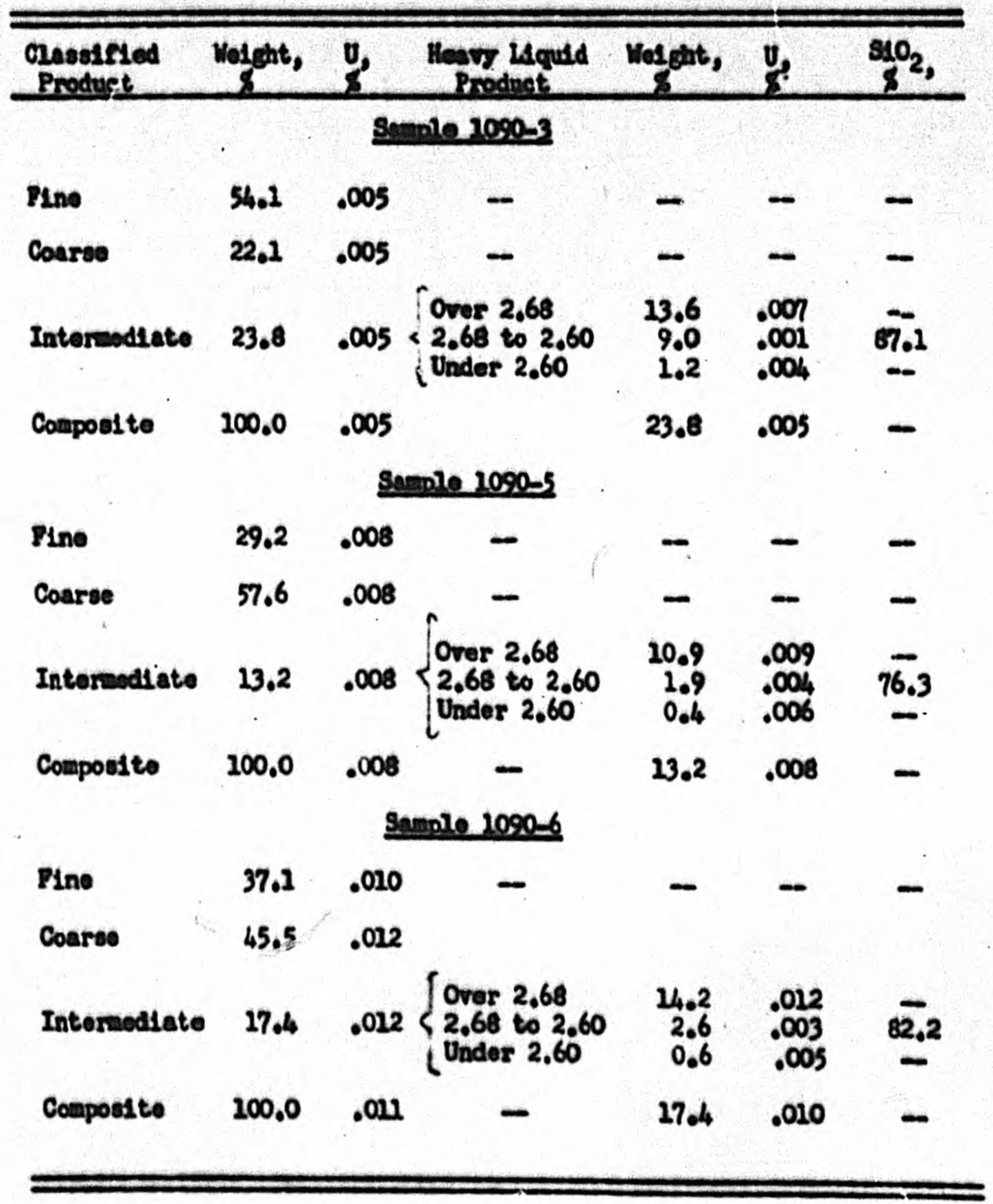


Progrese Report for the lonth of Apr11, 1947 Contract No. II-38-094-eng-27

Vee of Sulphur Chloride

The oblorinatios teste on Sample 4 , as deseribed on pages 272-173 in the roport dated lareh 21, 2947, were ropeated ualing eulphur chlorido in place of pure ohlorine gas. The sulphur chlorldo was propared by bubbling netored anounts of chlorino through a solton sulphur bath. This oulphur bath wee bold at 275\%. At this teaperature the chlorino forsed sulphur chloride readily, which was then paesed over the ore charge contained in a Pyrex brand pipotte In an eloctrle tube surnace. Bach saaple was hold at $662^{\circ} \mathrm{F}$. for' 3 hours. The amount of chlorine (and, tharefore, a proportlonats amount of sulphur chlorlda) was varied from $25 \mathrm{cc}$. to $2200 \mathrm{cc}$. por ainute. It was hoped that an excese of the reacting gas would tend to oweep eray any volatile uranlua oospounds that might be formed. The results of these teats, howevor, Indicated that auch an effect was not attained. The tests in which large esounts of oulphur chloride were used gave residus of approxinately the seme uranien content as those tosts in which enaller anounts of sulphur chlorids were used.

These results were chocked by both bete-count and chealcal essags and are in egreenent alth those results obtained from of milar teato (peges 172-273) In which pure chlorine was used Instesd of sulphur chlorlds. Thoy aloo subotantiato the previous Indication that sulphur chlorlde will, under olailar conditions, reacove bout 5.0 per cent nore uraniua than chlorine.

\section{O1l-Shale Distizlation}

In the roport of varch 31, 1947, It was stated (page 174) the sample of ofl shale, Sample 2090-4, had undargone a serles of destructive distilletion tests. The distillations were carried out in a quarts retort in a vertical

$$
957-20
$$


Progress Report for the Uonth of April, 2947 Contract No. W-38-0y/4-eng-27

electric tube furnace with an attached water cooled condeneer for the offluent gases. The samples were heated to about $800 \%$, for 20 hours and then the teaperature was raised to $1100^{\circ} \mathrm{F}$. for the subsequent 4 hours of treatment. The results of the teots were as follows

The ore loot, on an average, was 14.5 per cent of the original weight. The amount of free carbon resalning in the residues was 10.2 per cent. The total loss on 1gnition of this ore was 24.7 per cent. The water cooled condenser recovered about 4 per cent of the weight of the rav ore, leaving about 10.5 per cent unrecovered. The condensate contained 44 per cent oil and 56 per cent water. The oil, which anounted to 5 gallons per ton of shale, was roughly 1/3 unsaturated aromatics and olefines, and 2/3 saturated pareffins. Since it is probable that this ore would be heated prior to any metallurgical treatment, the above tests indicate some valuable products mizht be recovered during this period of preheating. hssays by beta-count and chemical analyses showed there was no apparent uraniua elinination from the ore by this treatment,

\section{Therrale Reductions}

Since metallic uranium is being prepared at the present time by the reduction of urantun tetrafluoride with magnesium, the effoct of rechucing agents such as $\mathrm{Hg}, \mathrm{Al}, \mathrm{Fe}$, and $\mathrm{Sn}$, on Samples 1090-4, -5, and - 11, was investigated.

The finely ground ore was wixed with 10 to 20 per cent, by weight, of the metal and heated to $1472^{\circ} \%$. When magnesiur was used, a Mash point was reachod which Indicated a violent exotherrile raaction. Charges with the other motals gave no such indications. 
An evaluation of the products of these tests is now under way. PreIiminary assays by beta-count indicate there was no appreciable volatilieation of uranium from the samples of 4,8 , or 11 in combination with any of the four metals mentioned above.

Weroscopic examinations of super-panner concentrates of the products are being made to detect any metallic uraniur that may have been formed by this reduction.

\section{Pyrometallurgical Tests in a Varuum Furnace}

A series of tests was performed last month in which Ores $i, 8$, and 11 were tested in a furnace under vacuum.

Figure 3 shows the details of the construction of the induction furnace used in the vacuum testing. The drawing is to scale and the quartz furnace tube is 24 -inches long and $4-1 / 4-1$ nchee outer diameter. The furnace was designed to give a positive vacuum seal ano to permit easy access to the charge. By removing the flange on the ufper portion of the furnace it is possible to remove the crucible containing the charge and replace it wi th anothar crucible in a matter of 2 or 3 minutes.

Pi gures 4 and 5 show two viexs of the PSE pumping system with attachid electric reduction furnace. The system of valves persits any corabination of pusping from the furnace. The procedure smployed was to preneat the charge slightly while open to the atmosphere. Then the furnace was sealed airtight and the entire systen (furnace, di fiusion pump, and lines) evacuated by the Eeshanical fore-puap to the noalial operating pressure of the fore-pump. The diffusion pupp was blanked off fros the furnace and was started in operation

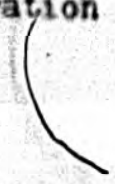




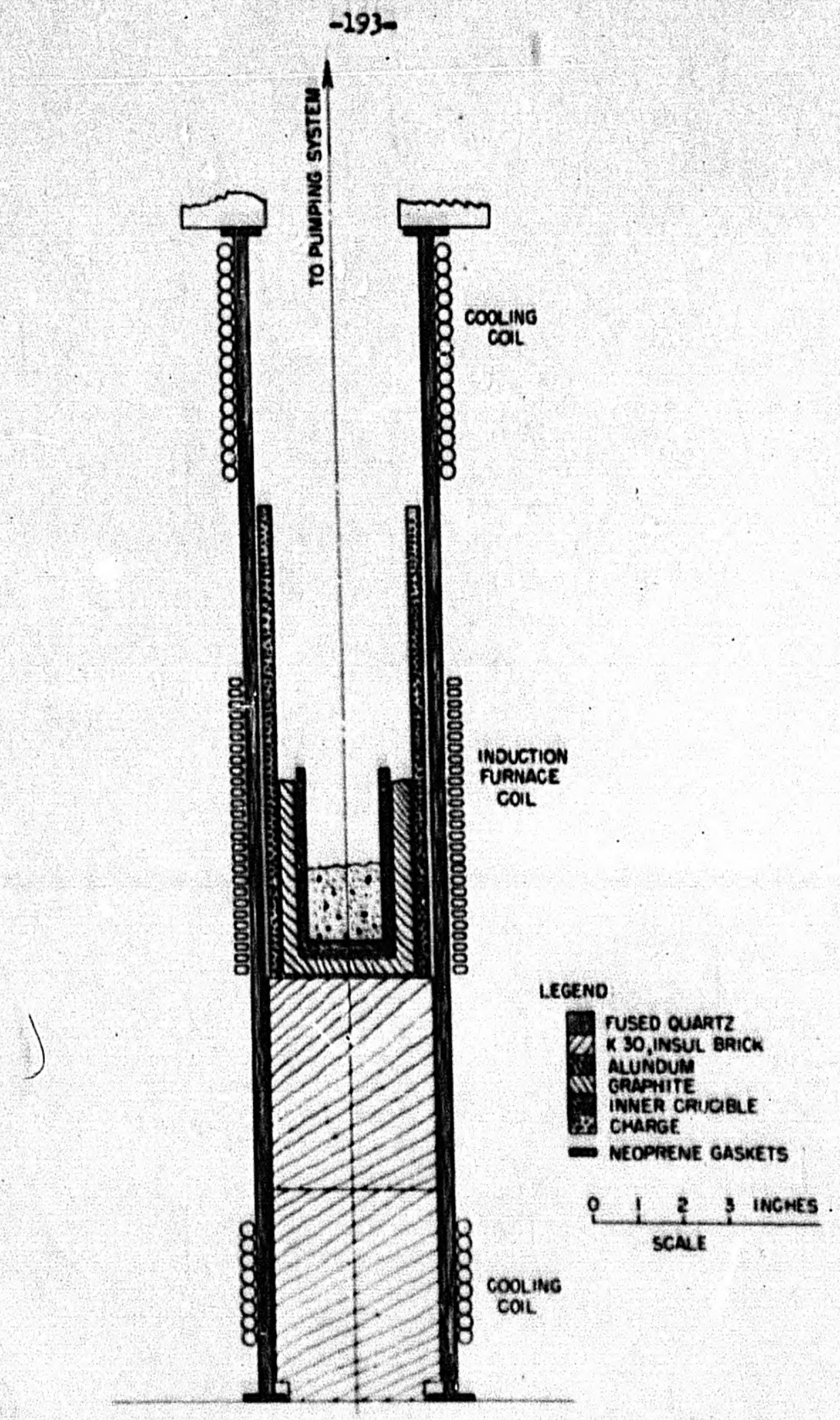

FIGURE 3 -ELECTRIC INDUCTION FURNACE FOR VACUUM TESTING 


\section{rigure L, Legend}

A. Cold trap

B. Cold-trap houalng

C. Alr-1nlot velres (2)

D. Control box, front viow

B. Plirent vacuin gauges (3)

7. Sulteh box for Eochanicel pump

c. Cooling vater hoses

H. Trane, PSE

I. Caster theel

J. Valve between furnece and diffusion pump

R. Coolling colle on surnace (2)

L. Valve between surnace and forepuap

N. Quarts Rurnece tube

N. Valve betweon forepung and dirruelon paip

0. Eetraust port

P. Irveel, forepunp

Q. Nechenicel forepuap houelng

R. Thorwoowiteh 


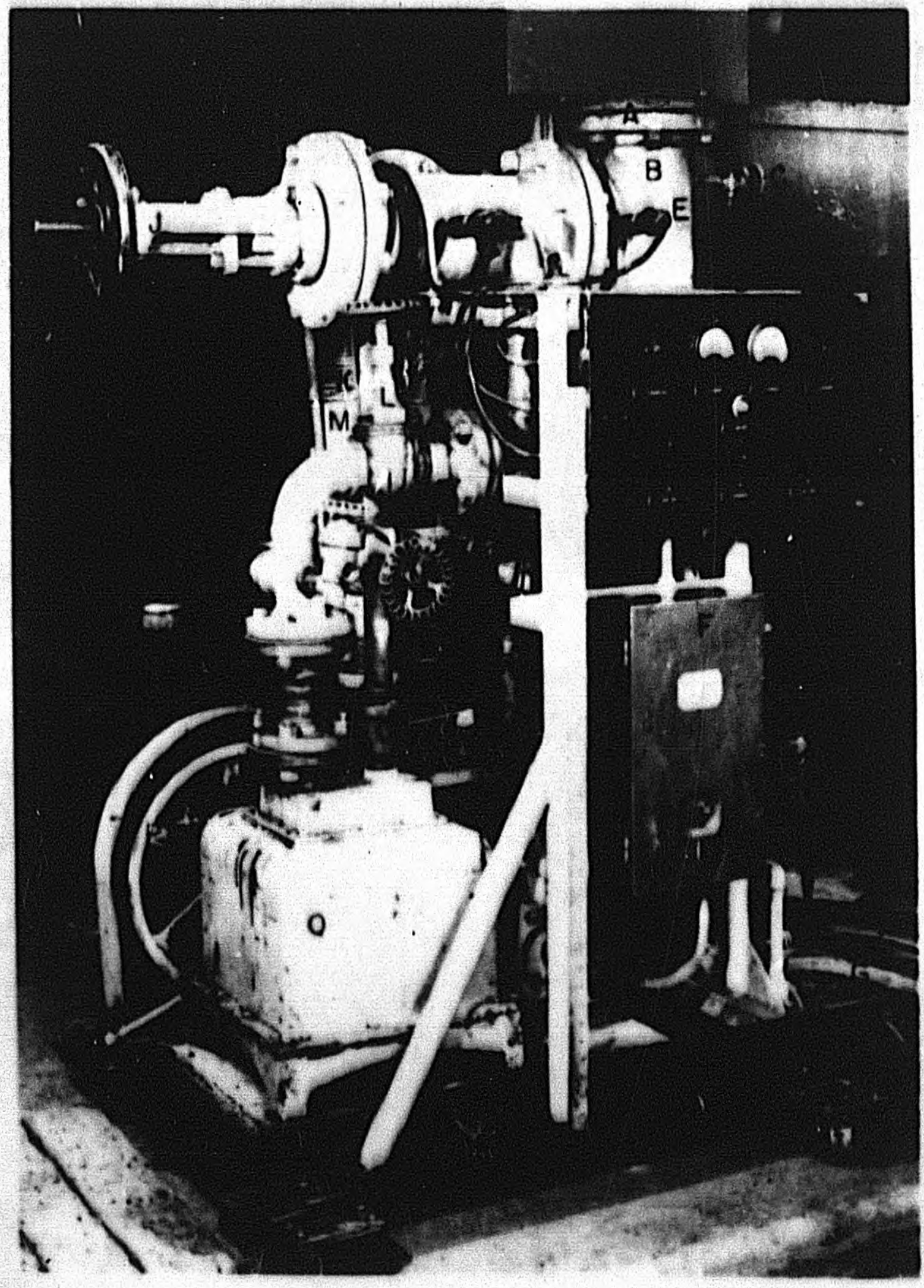

F1gure 4. PSE Pumplng Systea and Induction Furnace

49194 Front View

$$
457-25
$$




\section{Floure 5, Legend}

A. Cold trap

B. Vlalon port, eye pioce

C. Resovable slange on top of furnace

D. Valve betwoen difrusion puap and furnece

B. coollng collo (2)

7. Induct1on-Nurnace co11

0. Quarts rurnace tube

H. Nechanical foreptimp housing

I. Frame, PSB

J. Cester wheel

R. Stand, for taking readings

L. Cold-trap housing

M. Control box, rear view

N. Coollng water tubes

0. Dirfusion puap

P. Calrod heater unit in aifrualon puap

Q. Cooling vater hoses

R. Pover lines

S. Neoprene gasiket

T. Air-Inlet valve 


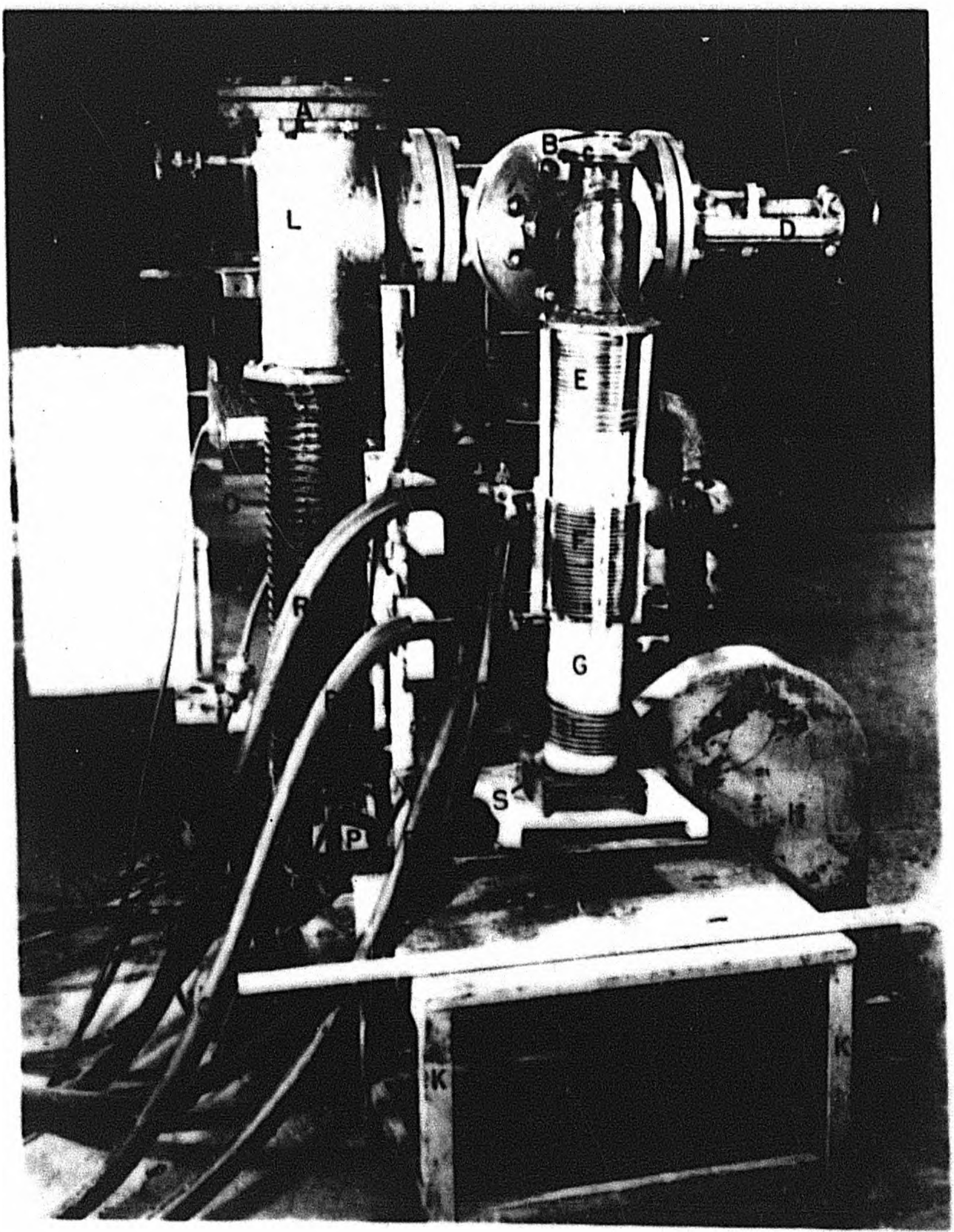

Fifure 5. PSE Pumping System and Induction Purnece

49193 Rear View

$$
957-27
$$




\section{$-196-$}

Progress Report for the Wonth of April, 2947 Contract No. W- $18-0944-e n 8-27$

with the fore-pump continuing to hold the vacuum on the rurnace, as well as act as fore-pump or rougher pump for the diffusion pump. when the difrusion pump is operating efficiently, valves are adjusted so as to place it in series with the mechanictil fore-puap, and both pumps are then evacuating the furnace, the diffusion pump acting as the finishing punp and the fore-puap as the primary or rougner puap.

One of the samples tested in this vacuum furnace was a slag comparable to a standard phosphorus furnace product. This slag was prepared from Sample 1090-11 by sasiting with silica and coke. The phosphorus content was less than 0.05 per cent, and there had been an elimination of 20 per cent of the uraniun, as determined by beta-count assays.

The slag underwent further preparatory treatsent by being oxidised by roasting at $1652^{\circ} \%$. for 4 hours with endium nitrate. The amount of ni trate added was 10 per cent of the weight of the slag. The roasted product was cooled, ground, and mixed with sodium flueride added to the amount of 10 per cent of the neight of the sample. The mixture was nelted in the vacuun furnace and held at the fusion tomperature of $1112^{\circ} \%$. for is hours, under a pressure of less than 1 micron. The final slag is undergoing chealcal analysis to deterat ne the extent of urani un elimination.

other tests under vacuum included a $\mathrm{FeS}_{2}$-NaCl roast, smelting, and roasting of the three representative ores. Results have not yet been confirmed by chealcal aspays, but prelieinary beta-counts on products do not indicate any appreciable elimination of urantun values by this metnod of treatacri. 